\title{
Molière Oyunlarında Kadın Karakterler ${ }^{1}$
}

\author{
Doç. Dr. Şengül KOCAMAN
}

Dicle Üniversitesi,Ziya Gökalp Eğitim Fakültesi,Yabancı Diller Eğitimi Bölümü,Fransız Dili Eğitimi Anabilim Dalı

\section{Özet}

Fransız edebiyatında 17. Yüzyıl denildiğinde ilk akla gelen yazarlardandır Molière. Mihail Afanasyeviç'in ifadesiyle "Çağdaşımız Molière" hakkında yapılan sayısızca çalışmalara rağmen, hala kendinden ve eserlerinden söz ettirecek kadar güncelliğini kaybetmeyen bir yazar. Peki, nedir Molière'i bu kadar evrensel kılan? Yazarlığı, şairliği, oyunculuğu, tiyatro yönetmenliği bir yana, biz onun başarısındaki en önemli etkenin onun o üstün gözlem gücüne dayandığını düşünüyoruz. $\mathrm{O}$, insan doğasını bütün ayrıntılarıyla görmesini, gözlemlemesini ve oyunlarına aktarmasını bilen ender yazarlardandır. Tiyatroyu toplumun bir aynası olarak nitelendiren Molière, yaşadığı dönemin aksaklıklarını, kusurlarını, bütün sahte değerleri gülmeceyle birleştirip sahneye taşır. Tabi bundan kadınlar da nasibini alır. Oyunlarının birçoğunun başlı̆̆ında yerlerini bulan kadınlar, Molière tiyatrosunda 17. Yüzyıl Fransız toplumunu tiyatroya yansitmak, komiği oluşturmak, doğanın, doğallığın öneminin vurgulamak için de önemlidirler. Çalışmamızda, hem 17 yüzyıl hem de o yüzyılda kadının toplum içindeki konumu hakkında genel bir bilgi vermeyi hedefliyoruz. Molière oyunlarının dramaturjik analizi için 17. Yüzyılın siyasal, toplumsal özelliklerini sık sık göz önünde bulundurmaya çalıştık.

Anahtar Kelimeler: Cimri, Komik, Presyozite, Klasisizm

\section{Female Characters in Molière's Plays}

\begin{abstract}
Molière is the first writer who comes to mind when the topic comes to the 17th century in French literature. Despite a myriad of studies on "Our contemporary Molière" by Mihail Afanasyevic's statement, he is still a writer who does not lose his actuality to mention his self and his works. Well, what makes Molière so universal? Apart from his identity of writer, poet, actor, theater director, we
\end{abstract}

\footnotetext{
${ }^{1}$ Makale Geliş/Kabul Tarihi: 17.09.18/19.03.19

Kün.: Kocaman, Ş. (2019). Molière Oyunlarında Kadın Karakterler. Kahramanmaraş Sütçü İmam Üniversitesi Sosyal Bilimler Dergisi, 16 (1), 167-179. DOI: 10.33437/ksusbd.460574
} 
think that the most important factor in his success depends on his superior observation power. He is one of rare writers who know how to see, observe and transmit human nature in all its details. Molière, who describes the theater as a mirror of the society, uncovers the faults, flaws, and all the fake values of his time and brings them on the stage by combining with humor. Of course, this situation has also influence on women. In Molière's theater, women who find themselves at the title of his many plays are also important for reflecting the 17 th century French society to the theater, for creating comic, and for emphasizing the importance of nature, of naturality. In our work, we aim to give a general knowledge of both the 17th century and the position of women in society in that century. For the dramatical analysis of Molière's plays we have often tried to consider the political and social features of the 17th century.

Keywords: The Miser, Comic, Preciosity, Classism.

\section{GİRIŞ}

Sevda Şener "Tiyatro Eserimizde Kadın Imajı" adlı makalesinde, yazarın yaşadığı dönemle ilişkisi için “...yazarın oyun kişilerini yaratırken onları, içinde yaşadığı toplumun genel kanısına uygun olarak tipleştirdiğidir" der. (1990: 467) Molière'de gerçek yaşamda gördüklerini oyunlaştırmada son derece başarı gösteren yazarlardan biridir. Oyunlarında soylulardan köylülere, burjuvadan uşaklara toplumun her kesiminden kişiler vardır ve oyunlarını yazarken asıl "kuvvetini hayatın kendisinden alır. Böylelikle sahnede hem bir dönemin rengini, özelliklerini göstermeyi başarmış hem de insanoğlunu kudretli bir görüşle çözümlemeye çalışmıştır." (Tuncel 2011: 7) 17. Yüzyıl Fransız komedya yazarı olarak Molière'in oyunlarını okumak ve incelemek o dönem Fransa'sını sosyal, kültürel, ekonomik gibi birçok açıdan görmek gibidir. Yazarın içinde bulunduğu çağ ve toplumla ilişkisine değinen Berke Vardar'ın belirttiği gibi:

Yazar istediği kadar çă̆ını aşmak istesin, aşamaz. Çağının adamı olmaya mahkûm. Şu ya da bu biçimde çağdaş toplumu da eserinde canlandıracak ister istemez. Çünkü onun için elle tutulur, gözle görülür tek yaşayan gerçek çağdaşları ve toplumu. XVII. Yüzyılda da durum değişik değil. O çă̆ın yazarları da, evrensele dönük olmakla birlikte, toplumlarını da yansımışlardır eserlerinde. (1998:110) 
Şüphesiz bu güne dek Molière hakkında sayısız tezler, makaleler yazılmıştır ve yazılmaya devam edilmektedir. Bütün bunlar Molière mizahının inceliğinin, derinliğinin belirtileridir. Yapılan çalışmalar arasında yerini bulacak bu makalemizde Molière oyunlarında kadın karakterleri hedef olarak belirledik. Çıkarcı kadınlar, özentilerle yaşayan kadınlar, korumacı sağduyulu kadınlar, boyun eğen kadınlar, tiyatroyu toplumun aynası olarak gören Molière'in oyunlarında rastladığımız kadın karakterlerdir. Birbirinden farklı davranış sergileyen bu kadınlar taşıdıkları tüm özellikleriyle bir yandan yaşadıkları yüzyılın kadınını simgelemiş diğer yandan da yaşadıkları toplum yapısı, insanların o dönemdeki davranışları hakkında bilgilenmemizi sağlamışlardır.

Tiyatro eserlerinde yansittlan kadin imgesini incelerken kadin tiplemesinden yararlanmak, toplumun o tipin temsil ettiği küme hakkında ortak görüşü hakkında bir fikir verecektir. (Şener, 1990)

Çalışmada başlıklarında kadın isimlerinin bulunduğu Kadınlar Mektebi, Bilgiç Kadınlar gibi oyunlar önceliğimizi oluştursa da, Molière'in ünlü oyunu Cimri'deki Elise'i göz ardı etmedik. Yazarın kadın kahramanları üzerinden 17. yüzyıl kadın sorunsalına bakış açısını incelemeye, 17. yüzyıla ait Fransız toplumunun gelişim sürecini yazarın oyunları aracılığıyla göstermeye çalıştık.

\section{Kadınlar ve Evlilik: Cimri'nin Elise'i, Kadınlar Okulu'nun Agnès'i}

Cimri'yi kısaca hatırlamak gerekirse, zengin bir o kadar da cimri olan Harpagon tefecilik yaparak daha fazla zenginleşmeye çalışan küçük bir burjuvadır. Yaşamdaki en büyük amacı zenginleşmektir. Daha fazla zengin olmak, mümkün olduğunca da daha az para harcamak. Paraya olan tutkunluğu nedeniyle kızı Elise'i varlıklı aynı zamanda soylu bir ihtiyarla, oğlu Cléante'ı ise zengin bir dulla evlendirmek ister. Kendisi ise, Cléante'ın âşık olduğu genç ve güzel Mariane'la evlenme hazırlığı içindedir.

Oyun, baş oyun kişisi Harpagon'un cimriliği üzerine kurulu olup, servetini çaldırma korkusu içinde yaşayan bir babanın düştüğü komik durumları konu edinse de, yazar bu ana tema etrafinda "trajik" sayılabilecek başka temalara da yer verir: Despotizm, bencillik ve kadın gibi. Bu bağlamda, Cimri, ayn zamanda paradan başka bir şey düşünmeyen ve evde tek hâkimiyet olarak kendini gören bir babanın kızı olan Elise'in dramıdır da... Kadın karakter olarak Elise, oyunun merkezinde değildir ancak kadın olarak karşılaştığ 1 sorunlar önemlidir. Yazar, ataerkil değerlerin baskın olduğu bir toplumda kadın ve erkek arasındaki eşitsizliğe dayalı ilişkiyi göstermeyi de amaçlar. Harpagon'un çocuğu olma talihsizliğini yaşayan Elise, babasının cimriliği yüzünden varlık içinde yokluk yaşamaktadır. Daha da önemlisi, istemediği 
biriyle sırf zengin olduğu için zorla evlendirilmek istenmektedir. "Harpagon:. (...) evleneceksiniz kendileriyle, hem de bu akşam. ..." (Molière, 1983: 35-36) Böyle bir koca Harpagon gibi bir babanın işine gelir. Çünkü bu soylu zengin koca adayı, kızı çeyizsiz alacaktır. Üstelik damat adayının "malı mülkü dillerde" Bir kadın daha fazla ne isteyebilir ki... "Kaçırılmaya gelmez böyle bir fırsat; hemen atılmalı üstüne. Bir daha da ara bul böylesini." (s.37) Nas1l ki ülkenin tek hâkimiyeti kralsa, (XIV. Louis'nin "Devlet benim" sözünü hatırlatmak gerekir) ailede de tek söz sahibi, babadır. 17. yüzyılda ailede baba, kralın temsilcisi gibidir. Edmond et Jules de Concourt'un belirttiği gibi, Tanrı'nın temsilcisi kral, kralın temsilcisi ise babadır ve bunlar yasal güçlerdir. Onların otoritesine karşı gelmek suçtur. (le père représentant du roi, et le roi envoyé de Dieu, sont les maitres légitimes. Et se dresser contre leur autorite serait sacrilège) (1882:139) Devlet yönetiminde de, aile içinde de erkek önceliklidir. Aile içinde erkek aile değerlerini koruyan, tüm aileyi yönlendiren, otoritenin onun elinde toplandığ kişi konumundadır. Bir yandan mutlak ve sonsuz otorite Harpagon diğer yandan ise ikinci plana itilen, edilgen bir nesne konumuna getirilen Elise.

Neden Harpagon? Neden Molière Harpagon gibi son derece cimri, paranın yaşamak için tek amaç olduğu, kızını dahi kâr getiren bir obje gibi gören bir tip yaratmıştır? Bunun yanıtını yine yazarın yaşadığı toplumsal değerler içinde aramak gerekir. 17. Yüzyıl Fransa's1 kapitalist değerlerin toplumsal ve siyasal yaşamı en derinden etkilediği bir dönemdir. "Feodal ekonomiden sanayiye dayalı bir ekonomiye geçiş dönemidir. Yeni bir dünya, eski feodal toplumun yerini alır." (Michel, 1993: 40) 17. yüzyıl, aynı zamanda, ülkenin yaşadığı ekonomik sıkıntıları hafifletmek için kralın "soyluluk unvanını" belli bir bedel karşıllı̆ında, ticaretle uğraşıp zenginleşen burjuva sınıfina sattığı 1 ve sonradan soylu olan bir toplumsal tabakanın ortaya çıktığı bir dönemdir. Bu yüzyıla kadar kalıtsal yollarla aktarılan soyluluk unvanı, artık bu özelliğinden uzaklaşmış zenginleşen burjuva kesimine satılan bir unvan olmuştur. Gerek siyasal ve gerekse toplumsal saygınlık elde etmeye başlayan bu sınıf, feodal yapının kırılmasını, kapitalist değer yargılarının ortaya çıkmasını sağlar. 17.yüzyıl, bir ölçüde, feodal düzenin kapitalist düzene dönüştüğü bir dönemdir:

Bu yüzyılı önemli tarihsel köşe taşlarından biri haline getiren en önemli nokta ise kapitalist değer yargılarının ortaya çıkışıdır. Feodal değerler içerisinde bireyin toplumsal prestiji doğduğu statüden kaynaklanirdl. Herkesin "kendini bilmesi", toplumsal konumu içerisinde her hangi bir yükselme hırsindan uzak durması, var olan statik toplum yapısinı bozacak eylemlere meyletmemesi anahtar değerlerdi. (Keskin, 2009: http://art-izan.org/moliere) 
$\mathrm{Bu}$ bağlamda, Cimri sınıf ve soyluluk gibi kavramların sadece paraya dayandığı, yeni değerler sisteminin oluştuğu bir dönemin ürünüdür diyebiliriz. Yatırım yapmak, daha fazla para kazanmak, daha fazla saygınlık elde etmek hırsının doruk noktada olduğu bu dönem toplumunu alaylı bir şekilde oyunlarında ele alan Molière, bu yeni değerlerin beraberinde getirdiği değişimleri ve bu değişimlerin kadın üzerindeki olumsuz etkilerini Cimri adlı eserinde son derece başarılı bir şekilde gözler önüne sermektedir. Devletin küçük bir alt yapısı olan ailenin burjuva sisteminde dağılması, yenilgisi anlatılır. Burjuva düzenin getirdiği para hırsı ile aile arasındaki ilişkileri asgari bir düzeye indirgenmiş, aileye verdiği zarar açıkça gösterilmiştir. Nesnelerin, eşyaların hatta insanların değeri yok, artık fiyatları vardır. Nitekim, Harpagon için de kızı Agnès'in evliliği, mutlu bir birliktelikten ziyade kârlı bir iştir. Keskin'in Molière Eğitim Araştırma Projesi: Tarihsel Arka Plan Çalışması'nda ifade ettiği gibi, dünya düzeninin belirgin bir değişim yaşadığ 1 bu dönemde Molière burjuva değerlerinin eski statik toplumu sarstığının farkındaydı ancak yeni değerlerin toplumsal yaşamda yaratacağı yozlaşmayı da seziyordu. Bu yüzden sadece özenti burjuvalar yaratmakla kalmadı, Sganarelle veya Harpagon gibi cimri, bencil, kadınları alınıp satılabilen birer nesne olarak gören, her konuda kendi çıkarından başka bir şey düşünmeyen vs. tipler de yarattı. (2009)

26 Ocak 1662 'de Paris'de Palais-Royal Tiyatrosu'nda oynanan Kadinlar Okulu adlı oyunu ile Molière, Harpagon kadar cimri olmasa da, onun kadar bencil olan başka bir kahramanla tanıştırır bizi. : Arnolphe. O, kırkını geçtiği halde henüz on altısını doldurmamış olan Agnès'le evlenme sevdasındadır. Agnès'i daha dört yaşındayken onu fakir annesinden alıp, her türlü bilgilenmesini engelleyecek şekilde dünyadan uzak bir biçimde büyütür, evlilik çağına geldiğinde de onunla evlenmeyi düşünür. Arnolphe evlenmek için çeşitli oyunlara başvursa da, Agnès, Horace isminde bir delikanlıya gönlünü kaptırır. Sonuçta genç kız, sevdiği delikanlıyla evlenir.

Kadınlar Okulu'nda Molière kadınla ilgili sorunsalı biraz daha ileriye götürür: Bu kez kadın, bir babanın değil, 14 yaşındaki bir genç kıza kendisini bir koca adayı olarak gören 40 yaşındaki bir erkeğin baskısı ve zulmü altındadır. "Oyunun asıl konusu tıpkı Gülünç Kibarlar, Kocalar Mektebi gibi kadındır”. (Tuncel, 2011: 7)

Evlenmeden önce babasının emrinde olan kadın, evlendikten sonra da kocasının emri altına girer. Kendi çıkarları için çocuklarını evlendiren otoriter bir babadan, sevmeden evlenilen bir kocanın egemenliği altına giren kadının durumunu sosyal bir yara olarak gören Michel de Pure La Prétieuse ou le Mystère des Ruelles adlı eserinde 17. yüzyıldaki kadının konumuyla ilgili şöyle der: 
Evlilik, kadının öncelikle kendi çıkarları için çocuklarını evlendiren otoriter babanin ve sonrasinda da sevilmeyen, bu otoritenin devamını getiren koca yüzünden kurban olduğu sosyal bir yaradir. (Le mariage est une plaie sociale dont la femme est la principale victime, d'abord à cause de l'autoritarisme du pere qui marie ses enfants en vue de son seul intérêt. Ensuite, à cause du mari qu'on n'aime pas et qui prolonge la domination paternelle.(1882: 140)

Arnolphe'ın bir evlilikte kadından beklentileri Pure'in söylemini destekler niteliktedir:

\begin{abstract}
Arnolphe: ... Evlilik çocuk oyuncă̆l değildir Agnès. Evli bir kadının çok ciddi görevleri vardır. Ben sizi bu duruma her istediğiniz yapıp, keyif sürmeniz için getirmiyorum. Kadın kısmına düşen itaattir. Sakal kimdeyse bütün kuvvet ondadır. Gerçi ailenin bir parçası erkek, bir parçası da kadındır, fakat parçalar arasında eşitlik yoktur; biri yukarlda diğeri aşağıdadır, biri emreder, diğeri boyun ĕger; görevini bilen bir askerin üstüne, uşağın efendisine, çocuğun babasına, çömezin hocasına gösterdiği itaat, kadının kocasına, aile reisine, velinimetine, efendi si olan insana, duyacağ derin saygının, alçakgönüllülüğün, itaatin, boyun eğişin yanında hiç kalır. (Moliere, 2011: 3)
\end{abstract}

Görüldüğü gibi, evlilikte, kadına yüklenen sorumluluk ağır, zahmetli ve acımasızcadır. Kadın, kurallarını erkeğin koyduğu bu kurumda bir köle olarak yaşamını devam ettirmek zorunda kalan zavallı konumundadır. Evliliği süresince kadının evde söz söyleme hakkı yoktur. Evine hapsedilen kadının bilgi düzeyi de kocasının ona sunduğu hayat kadar sınırlıdır. Kadın için kocası ne derse doğrudur. Erkek evlilikte kendine en yüksek statüde yer edinir, kadın ise sadece onun arzu nesnesidir: Kadın ancak ona sahip olan kocasinin arzu ettiği kadar süslenmeli. Güzelliğine göstereceği özen yalnı kocası için olmalıdır. (s.34) Dolayısıyla, gerek Cimri'de gerek se de Kadınlar Mektebi'nde itaatkâr, baskı gören, belirlenmiş rollere sıkıştırılan bir kadın imajı çizilmektedir. Ancak, unutmayalım ki, her iki oyunun sonunda da zafer kadınlarındır. Zekâları sayesinde'Agnès'in Arnolphe'u, Elise'in de Harpagon'u oyuna getirip, istedikleri kişiyle evlendikleri görülür.

\title{
Kadın ve Salonlar (Presyozite) : Bilgiç Kadınlar
}

1672'de yazılan Bilgiç Kadınlar oyunuyla Cimri (1668) ve Kadınlar Okulu (1662) oyunları arasında epey bir zaman aralığı görülmektedir. Bu zaman 
içerisinde kadının aile ve toplumdaki gelişim süreciyle ilgili olarak Bilgiç Kadınlar bize önemli ipuçları vermektedir. Artık, eve ya da manastıra kapanan kadınlar değil, evinden dışarı çıkmış hatta sosyal hayata katılmış kadınlar söz konusudur.

Bilgiç Kadınlar'da, bir burjuva olan Chrysale'in evi, karısı Philaminte, kızkardeşi Belise ve kızı Armande tarafından bir edebiyat salonu haline dönüştürülmüsşür. Kültürel, bilimsel toplantıların yapıldığı salonlar, sanat çevresinin merkezi konumunda olup, Chrysale'in ailesindeki kadınları da etkilemiş, onlar da evlerini bir bilim kültür merkezi salonu haline getirmişlerdir. Olayı evin babası Chrysale ve ikinci kızı Henriette abartılı bulur ve günün modası olan salon aktivitelerine katılmazlar. Henriette bu modaya aldırmadığı gibi, ablası Armande'ın felsefeye önem vermediği için geri çevirdiği Clitandre ile evlenmeyi düşünmektedir. Oysaki Henriette'in annesi ve halası onu Trissottin adında "yüksek kültür", "bilim" ve "felsefe" sahibi Trissottin'e vermek isterler. Oysa Trissottin evliliği Henriette zengin olduğu için istemektedir. Sonunda Henriette'nin amcas1 Ariste bir sahte mektup ile ailenin tüm servetini kaybettiği haberini yayar. Bunu üzerine Trissotin evlilikten çayar ve evliliği para için yaptığını açıklar ve buna çok kızan Philaminte kızı Henriette'in Clitandre ile evlenmesini kabul eder. Oyunda birbirinden tamamen farklı düşünen iki kız kardeşin zıtlıklarla dolu konuşmaları ilgi çekicidir:

Armande: Aman Allahım! Ne kadar bayağı bir ruhunuz var! ... Gözleriniz Allah diye tapacak bir koca ile bir sürü yumurcaktan başka bir şey görmüyor. Bu gibi şeylerin vereceği bayağı zevki, kaba insanlarla âdi kimselere bırakın; arzularınız daha yüksek şeylere çevirin. ... Bir adamın emirlerine köle gibi itaat edeceğinize, bizi insanliğın üstüne çıkaran felsefeye kendinizi verin. (Molière 1944: 4-5)

Henriette: Yeryüzünde kalan benim ruhum evliliğin bayağı zevklerini tadarken, siz büyüklük ve güzellikten yoğrulmuş ruhunuzun hizlyla felsefenin yüksek ellerinde yaşayın; ... (s.5-6)

Cimri ve Kadınlar Mektebi'ndeki gibi her şeye boyun eğen, erkeğin sözünden çıkmayan kadın profilinden çok uzak, evlilik, çocuk sahibi olma gibi durumları küçümseyen, yaşamı sadece "felsefe ve bilimden" ibaret gören kadınlarla karşılaşıyoruz. Chrysale'in kardeşi Ariste, abisinin aile içindeki konumuyla ilgili olarak şöyle der:

Ariste: ... Lâf aramızda kalsın, korkaklı̆gınız yüzünden size hâkim olmuş. Onun kudreti sizin zayıflı̆̆ınız üzerine kurulmuş, efendilik 


\begin{abstract}
unvanın sizden alıyor; onun mağrur tahakkümüne kendinizi teslim eden sizsiniz, sakalınızl eline vermişsiniz, sizi istediği yere götürüyor. ... Kadına arzularını kabul ettirmeye, "Böyle istiyorum" diyebilecek kadar cesaret göstermeye yanaşmiyor musunuz? (s. 39)
\end{abstract}

Diğer iki oyunun aksine, bu kez evdeki söz sahibi, evin hâkimiyeti kadındadır. Üstelik bunlar bilimle uğraşan kadınlardır. Ancak çok geçmeden bilimle uğraşıyor gibi göründüklerini, bilimden başka amaçlar için yararlandıklarını öğreniyoruz. Philaminte başta olmak üzere, Henriette dışında evin kadınları bilgileriyle, görgüleriyle inanılmaz bir üstünlük sergilemekte, çevrelerindekileri yeterince bilgilenmedikleri için suçlamakta, azarlamakta, küçük görmektedirler. Philaminte'in hizmetçi kadın Martine'i ünlü bir dilbilgisi kitabına aykırı konuştu diye onu küstahlıkla suçlaması ve evden kovması gibi:

Philaminte: Emsali görülmemiş bir küstahlık yaptı. Otuz dersten sonra Vaugelas'nın katî ibarelerle dilimizden attığı âdi ve kaba bir sözü yersiz kullanarak kulağımı incitti. ... O kadar tembihler etmişken yine her zaman ilimlerin temeli olan ilmi sarf, kırallara bile hocalık eden, onlart bile elleri bağll kaidelerine itaat ettiren ilmi sarfi darbeliyor. Bu nasil olur?(s.28)

Cimri'deki Elise ve Kadınlar Okulu'ndaki Agnès'den bu denli farklı davranan Philaminte'i ya da kızı Armande'ı anlayabilmek için yine Molière'in yaşadığı dönemi bir kez daha gözden geçirmek gerekir: 17. Yüzyıl feodal sistemden kapitalist sisteme bir geçiş dönemi olmakla birlikte, Rönesans'ın yarattığ 1 gelişmelerin etkisiyle de, edebiyat, sanat ve kültür alanında önemli gelişmelerin de söz konusu olduğu bir dönemdir. Paris soyluların, edebiyat çevrelerinin merkezi haline gelir. Richelieu 1634'de Académie Française'i kurup, tiyatronun gelişmesine destek olur. Versailles Saray1 monarşinin görkemli bir simgesi konumuna sokan XIV. Louis, sanata, edebiyata her türlü kültürel aktivitelere önem verir. "Salon" denilen ve soylu kesimin sıklıkla gittiği ve edebiyat sohbetlerinin yapıldığ sosyal alanların oluştuğu bu dönemdir. Özellikle, bu salonlarda "gramer edebiyat üzerine konuşulur, duygular en ince ayrıntılarıyla incelenir, aşk üstüne dostluk üstüne ortaya atılan düşünceler en uzak sonuçlarına kadar götürülürdü. Ayrıca komedyalar oynanır, eserler okunurdu toplantılarda. Bu salonlarda toplanan kibar hanımlara "1656 yılına doğru presyöz (précieuse), kibar beylere de -daha sonraları- presyö (précieux),) denmeye başlanmış, çok geçmeden bu gibi kimselerin davranış, duygu ve dil özelliklerini belirtmek için bir kelime türetilmiştir: "préciosité". (Vardar, 1998:126) Söz konusu salonları kurup işletenlerin kadınlar oluşu son derece dikkat çekicidir: Salon (l'Hotel) de Mme Rambouillet, Salon de Mlle de 
Scudery, Salon de Mme Tencin, Salon de Mme Sévigné gibi. Kadınlar birçok alanda söz sahibi olmasa da salon gibi ortamlarda varlığını göstermeye başlamıştır artık. Bu anlamda, kadınların siyasal, toplumsal mücadelelerinin tam anlamıyla başladığı 18. yüzyıl için gerekli önkoşulların 17. yüzyılda hazırlandığı söylenebilir. 17.yüzyılda baş gösteren ve sonraki yüzyıllarda kadın mücadelelerinin başlangıcı sayılan bu salonlar ve salonlara giden kadınların konu edildiği Bilgiç Kadınlar'da, Molière kadınları yermek mi istiyor? Bu sorunun yanıtı için 17. Yüzyıl salonlarını biraz daha irdelemek ve Oflazoğlu'nun Presyozite hakkındaki açıklamalarına yer vermek gerekir:

"Préciosité (Presyozite) zaman içinde evrim geçirir, asıl işlevini kaybeder. Soylular sinıfinın kendi arasında bir şıklık ve nezaket yarışına dönüşür. Davranışlarda, jest ve mimiklerde hatta konuşma biçiminde yapmacıklığa varan bir tutum sergilenmeye başlanır. "On yedinci Fransız toplumunda, La Préciosité denilen tam bir kibarlık hastalığı” başlar. (Oflazoğlu, 1999: s.23)

Oflazoğlu, Presyozite için "hastalık" sözcüğünü kullanır. Gerçekten de sadece Fransa'da değil, dünyanın birçok ülkesinde de presyozite'ye benzeyen, farklı isimler altında ve toplumu özellikle de kadınları kapsayan ve kadınlar arasında bir hasatlık gibi yayılan birçok akım ortaya çıkmıştır. Örneğin, İngiltere'de öfüizm, İspanya'da gongorizm, İtalya'da marinizm akımları gibi. "Bunlardan son ikisi Fransa'daki gelişimi etkilemiş dış öğelerdir. Gogorizme göre edebî ifâde seçkinlik kazanabilmek için günlük ifadeden ayrılmalıdır. Marinizme göre ise, yaldızlı, parlak düşünce ve deyişler, beklenmedik nükteler her şeyde zorunlu ve yeterlidir.(Vardar, 1998: 127)

Bilgiç Kadınlar, Molière'in Paris'e dönüp saray himayesinde tiyatro yapmaya başladığı ve presyozite'nin baş gösterdiği dönemde sergilediği komedilerinden biridir. Yazar Parisli kibar hanımların özentili, abartılı dünyasını görür ve bunu oyununun konusu yapmaktan, onları eleştirmekten çekinmez. Bu kadın seyircilerinin şiddetli tepkilerine yol açar. Oyunda her türlü kibarlık özentisinin, yapmacıklığın keskin bir eleştirisinin sunulduğu açıktır. Philaminte, Armande gibi karakterler yaratması da dönemin özelliklerini, hastalık haline dönüşen kibarlıkları oyunlarına yansıtmak istemesindendir.

Presyozitenin bilgiçlik taslama yönünde bir evrim geçirdiğini çevresinde canl örnekleriyle gören Molière oyununda bunun tehlikeli sonuçlarını gözler önüne sermiş, böyle bir eğilimin giderek bütün aile düzenini bozacă̆ına işaret etmiştir.(Vardar, 1998: 173) 
Molière Gülünç Kibarlar'a yazdığı önsözde, amacının gerçek kibarları değil, sahte kibarları eleştirmek olduğunu belirtir. Ancak bu, onun oyunlarıla birçok kimseyi kızdırmasını engellemez. Yergi dolu oyunlarıyla yarattığı düşmanlıklar, onu ömrünün sonuna kadar rahat bırakmaz. Roger Lathuilliere, bu konuda Molière'in Rambouillet, Mlle Scudery gibi isimlerin önayak olduğu presyozite ile değil, bu işi abartıya götüren taklitçilerle uğraştığını belirtir:

Il est impensable que Molière ait voulu se moquer de la préciosité dans son ensemble, de l'Hôtel de Rambouillet, d'Arthénice ou de Mlle de Scudéry. Cette dernière d'ailleurs partait elle aussi en guerre contre la prétention de certaines imitatrices. (1882:145)

Molière'in hedefindeki kadınlar, özenti içinde olan ve o dönemin en yaygın sosyal, kültürel edebi faaliyetleri olarak kabul edilen salonlara gerçek amacı dışında gidip bunu sadece "gösteriş" adına yapıp abartanlardır. André Lagarde, Molière'in kadınla ilgili düşüncelerini belirtirken; Molière'in kadının okumasına, yazmasına, kendini geliştirmesine karşı olmadığını ancak kadının bilimi aşırı ya da kötüye kullanımının kadınlık cazibesini ve ev kadınlığ 1 kalitesini düşürdüğünü savunduğunu söyler:

Molière n'est pas davantage partisan des "femmes-docteurs". Grammairiennes, astronomes et philosophes, desséchées par l'abus de la science perdent leur charme feminin et leurs qualités de maitresses de maison. (Lagarde: 1961: 205)

Bilgiç Kadınlar önsözünde Hasan Ali Yücel, Molière'in kadınların birincil görevleriyle ilgili olarak düşüncelerini şöyle anlatmaktadır:

(Molière) Kadını dünyanın maddi, manêvi bütün nimetlerden erkek kadar hissesi olan bir mahlûk, çocuklarının anası, cemiyetin çekirdeği olan ailenin birinci unsuru, en mühim rüknü olarak sayıyordu. Kadının okumasina yazmasina, tahsil görüp aydınlanmasına da aleyhtar değildi. Onun istemediği, cemiyet için bir tehlike olarak korktuğu kadınların bir zevk süsü olmaktan kurtulup bir ilim süsü haline gelmeleri, bu suretle yaradılışlarında kendilerine verilmiş olan vazifeleri ihmalde devam etmeleriydi. Bilgiç Kadinlar'da konunun en göze çarpan noktası işte bu meseledir. (Bilgiç Kadınlar, Önsöz, s.XI-XII)

Klasik dönem yazarı Moliere'in kadın konusunda da "denge" unsuru üzerinde durması, ölçülülüğü temel alan eserler vermesi ve kadın karakterleri de 
bu kavramları göz önünde tutarak oyunlarına yerleştirmesi şaşırtıcı olmasa gerek.

\section{Kadın Doğa ve Doğallık}

Molière için doğa ve doğallık önemli bir kavramdır. Doğadan, doğallıktan uzaklaşan, yapaylaşan, toplumun genel kabul sınırlarını aşan davranışlarda bulunan insanların gülünç duruma düşmeye mahkûm olduklarını düşünen yazar çekinmeden onları oyunlarının konusu yapar. $\mathrm{O}$ halde Molière, oyunlarının temelinde yapmacıktan kaçınmalı (Les Précieuses Ridicules-Gülünç Kibarlar doğal eğilimleri güvenmeli, (Ecole des maris- Kocalar Okulu), Ecoles des femmes-Kadınlar Okulu), bilgiçlik taslamamalı (Les Femmes savantes-Bilgiç Kadınlar), kısacası, oyunlarında davranışlarımız akıl ve mantığın denetiminde olmalıdir.

Yukarda da belirttiğimiz gibi, Molière Bilgiç Kadınlar'da seçkin çevreleri saran sindirilmemiş, saptırılmış bilim tutkusunu eleştirir; bunun iyi kullanılmadığında amacından uzaklaştığını vurgular. " Molière'e göre bilgiçlik taslama illetine kendini kaptıran kadın doğal niteliklerini yitirir, gerçek görevlerini yapamayacak duruma düşer. Kadın önce bir eş ve bir annedir. Her şeyden biraz anlamalı (avoir des clartés de tout) ama bilgiç kadınlar gibi doğadan uzaklaşmamalıdır. (Vardar, 1998: 174) Yazar, kadınlardan da tıpkı erkeklerden istediği şeyleri ister: kibarlık, ölçülülük, kocalarını ve ailelerini sevme. Kadın-erkek ilişkilerinde de "tabiat" haklı konumdadır. Molière eserlerinde tabiat, daha doğrusu mantık ve selim akıl düşmanı olarak, bizzat mantıktan bahseden âlimlerin, profesörlerin, hekimlerin ve filozofların olduğunu görüyoruz. İşte, Arnolphe ve Alceste gibi, bunları, utanmadan...ak saçlarına bakmadan, on altı yaşında bir genç kızla evlenmeğe kalkışırlar!... Bütün bu ukalâlar, bu "âleme talkın verip de salkımı yutan" yobazlar hep Molière'in o zehir akıtan kaleminin hicvine, daha doğrusu hışmına uğradılar. (Perin, 1944: 96)

\section{Kadın ve Komik}

Molière "plaire au public" (seyircinin hoşuna gitmek) ilkesinden yola çıkarak oyunlarını yazar. Seyircisinin oyunlarını izlerken sıkılması onun en büyük kaygısıdır. Bunu engellemek adına başvurduğu en etkili yol, oyunlarını komedya türünde yazmak olur. Sözcük oyunlarından, olay örgüsüne ya da oyun karakterlerine değin her teatral öğe Molière oyunlarında komiği oluşturmak için kullanılır. Böylece hem oyunlarını izlemeye gelen seyircisini memnun etmiş olur hem de "gülünç" olandan hareket edip "yanlışı" göstermek ister. 
On yedinci yüzyllda Fransa'da Molière, insanlar en fazla etkileyen şeyin onları gülünçleştirmek olduğunu yazmıştır. Komedya, kusurların sergilenip gülünçleştirilmesi ile onların bilincine varılmasını sağlayacak ve bu yoldan kusurlardan kaçınılmasına yardım edecektir. Molière'in komedyalarında hayat gerçeğinin onaylanması ve doğal olana temellendirilecek olan davranışlar ile sağlıklı bir topluma ve toplum dengesine varılacağı düşüncesi yansimaktadır. (Sokullu, http://dergiler.ankara.edu.tr: 47)

Komedya "töreleri düzeltir; nasıl olmamız gerekiyorsa hemen öyle görünmeye çabalamamızı sağlar, sonunda da kuşkusuz öyle oluruz.”(Bergson 2011: 19) Molière "Paris'in ince yaşamını: kadınlar dünyasını görür, sarayın içinde olup bitenleri izler; ilçelerden buraya gelenlerin, parke taşlar üstünde nasıl yürüdüklerini gözlemler.” (Özgü, 2014) Böylece, Philaminte gibi özentili burjuvalar Harpagon gibi bencil, cimri ve kadınları satılan birer obje gibi gören tipler yaratmaktan çekinmez. Oyunlarında bu tipleri alaya alarak, beraberlerinde getirdiği yeni değerler ile seyircinin yüzleşmesini sağlar.

\section{SONUÇ}

Bundan yüzyıllar öncesinde de, şimdi de kadın ona yüklenen rollerden, baskı görmekten, ev içine hapsedilmekten ve toplumsal cinsiyet eşitsizliklerinden kurtulamamıştır. Çalışmamızda kadın konusu, aile içindeki kadın ve erkeğin rolü Molière oyunları ekseninde incelenmeye çalışılmıştır. Cimri oyununda 17. Yüzyıl Paris burjuvazisi ele alınmış paranın her şeyin üstünde bir değer olduğu, insani değerlerin özellikle kadının değerinin hiç sayıldığı bir toplum eleştirisi komediyle harmanlanmıştır. Erkek egemen toplum değerleri Kadınlar Okulu'nda Agnès-Arnolphe ilişkisi etrafinda Cimri'ye benzer özellikler sergilerken Bilgiç Kadınlar'la o yüzyılda toplumu kasıp kavuran ve bir hastalık gibi yayılan "özentiliğin”" eleştirisi yine kadınlar aracılığ ile verilmiş̧tir.

\section{KAYNAKÇA}

Bergson, Henri (2011), Gülme, Türkiye İş Bankası Kültür Yayınları, İstanbul.

De Concourt, Edmond et Jules (1882), "Le Feminisme à l'âge classique " La femme au dix-huitième siècle, Ernest Flammarion, Paris.

Keskin, İlker Yasin, (2009) Moliere Eğitim Araştırma Projesi: Tarihsel Arka Plan Çalışması, İlker Yasin Keskin 09.01.2009 http://www.bgst.org.) 
Lagarde, Andre et Michard Laurent (1961), XVII_siècle, Bordas, Paris.

Lathuillière Roger (1882), (Cite par Edmond et Jules de Concourt) "Le Feminisme à l'âge classique" femme au dix-huitième siècle, Ernest Flammarion, Paris.

Maité Albistur et Daniel Armogathe (1977), Histoire du féminisme français du moyen âge à nos jours, édition des femmes, Paris.

Molière, Jean Baptiste (1983) Cimri, Çeviren: Sabahattin Eyupoğlu, Remzi Kitabevi. İstanbul.

Molière, Jean Baptiste (1944), Bilgiç Kadınlar, (Çev: Dr. Ali Süha Delilbaşı), Maarip Batbaası.

Molière, Jean Baptiste (2011) Kadınlar Okulu, (Çev: Bedrettin Tuncel ve Sabahattin Eyüboğlu, Türkiye İş Bankası Kültür Yayınları, İstanbul.

Michel, Andre (1993), Çev: Şirin Tekeli, Feminizm, İletişim Yayınları, İstanbul.

Oflazoğlu, Turan (1999), Moliere, Cem Yayınevi, İstanbul.

Özgü, Melahat (2014), "Moliere'in 300. Doğum Yıldönümü Anısına" http://dergiler.ankara.edu.tr.

Perin, Cevdet (1944), Fransız Edebiyatında Komedi ve Molière, Rıza Koşkun Matbaas1, İstanbul.

Sevim, Ayşe (2005), Feminizm, İnsan Yayınları, İstanbul.

Sokullu, Sevinç, http://dergiler.ankara.edu.tr/dergiler/13/1160/13635.pdf

Şener, Sevda (1990), "Tiyatro Eserlerimizde Kadın İmajı", Dil ve TarihCoğrafya Fakültesi Dergisi, Sayı I, Cilt 33, http://dergiler.ankara.edu.tr/

Tuncel, Bedrettin (2011), Kadınlar Mektebi (Önsöz), Türkiye İş Bankası Kültür Yayınları, İstanbul.

Uygu, Erdoğan, Moliere ve Ahundof Tiyatrosunda "Cimri" Karakterleri: Harpagon ve Hacı Kara, http://dergiler.ankara.edu.tr/dergiler.

Vardar, Berke (1998), Fransız Edebiyatı, 1998, Multilingual, İstanbul. 